\title{
Putative biotic drivers of plant phenology :with special reference to pathogens and deciduousness
}

\author{
Rowland Burdon ${ }^{1}$ and Michael Bartlett ${ }^{1}$ \\ ${ }^{1}$ Scion (New Zealand Forest Research Institute Ltd)
}

November 30, 2021

\begin{abstract}
Plant phenology is manifested in the seasonal timing of vegetative and reproductive processes, but also has ontogenetic aspects. The adaptive basis of seasonal phenology has been considered mainly in terms of climatic drivers. However, some biotic factors as likely evolutionary influences on plants' phenology appear to have been under-researched. Several specific cases of putative biotic factors driving plant phenology are outlined, involving both herbivores and pathogens. These illustrate the diversity of likely interactions rather than any systematic coverage or review. Emphasis is on woody perennials, in which phenology is often most multi-faceted and complicated by the ontogenetic aspect. The complete seasonal leaf fall that characterises deciduous plants may be a very important defence against some pathogens. Whether biotic influences drive acquisition or long-term persistence of deciduousness is considered. In one case; of leaf rusts in poplars, countervailing influences of the rusts and climate suggest persistence. Often, however, biotic and environmental influences likely reinforce each other. The timing and duration of shoot flushing may in at least some cases contribute to defences against herbivores, largely through brief periods of 'predator satiation' when plant tissues have highest food value. Wide re-examination of plant phenology, accommodating the roles of biotic factors and their interplays with environments as additional adaptive drivers, is advocated, towards developing and applying hypotheses that are observationally or experimentally testable.
\end{abstract}

Title: Putative biotic drivers of plant phenology: with special reference to pathogens and deciduousness

Authors: Rowland D. Burdon (corresponding); ORCID number 0000-0002-7815-2739;Email: $<$ rowland.burdon@scionresearch.com $>$

Michael J. Bartlett; ORCID number 0000-0002-4253-6589

Address: Scion (New Zealand Forest Research Institute Ltd), Private Bag 3020, Rotorua 3046, New Zealand

Keywords: biotic interactions, evolution, deciduous, herbivory, pathogens, plant phenology

Manuscript category: Hypotheses

Words (total): 11,552; Main text - 8502

List of elements: manuscript only

\begin{abstract}
Plant phenology is manifested in the seasonal timing of vegetative and reproductive processes, but also has ontogenetic aspects. The adaptive basis of seasonal phenology has been considered mainly in terms of climatic drivers. However, some biotic factors as likely evolutionary influences on plants' phenology appear to have been under-researched. Several specific cases of putative biotic factors driving plant phenology are outlined, involving both herbivores and pathogens. These illustrate the diversity of likely interactions rather than any systematic coverage or review. Emphasis is on woody perennials, in which phenology is
\end{abstract}


often most multi-faceted and complicated by the ontogenetic aspect. The complete seasonal leaf fall that characterises deciduous plants may be a very important defence against some pathogens. Whether biotic influences drive acquisition or long-term persistence of deciduousness is considered. In one case; of leaf rusts in poplars, countervailing influences of the rusts and climate suggest persistence. Often, however, biotic and environmental influences likely reinforce each other. The timing and duration of shoot flushing may in at least some cases contribute to defences against herbivores, largely through brief periods of 'predator satiation' when plant tissues have highest food value. Wide re-examination of plant phenology, accommodating the roles of biotic factors and their interplays with environments as additional adaptive drivers, is advocated, towards developing and applying hypotheses that are observationally or experimentally testable.

\section{Introduction}

The phenology of an organism is among the key bases of evolutionary adaptation to its habitat. It involves timing of an array of developmental processes, with seasonal and ontogenetic aspects. With plants at least, phenology is generally addressed in terms of its seasonal aspect, which we mainly address. Seasonal phenology involves seasonal timing of growth and reproductive processes. The visible processes in plants include bud break in spring, shoot elongation, bud set in autumn, natural foliage shedding, production of flower (or strobilus in gymnosperms) buds, actual flowering, and development of fruit and eventual fruit drop or seed shedding. Phenology, however, can also include cryptic features (cf Albert et al. 2019). These include initiation and differentiation of primordia, seed development, timing of cambial activity, dehardening and hardening of tissues against frost, the nature of growth rings, and seasonal patterns in root development. However, we will not addrees specifically the cryptic phenomena, which include both precursors of and flowons from the visible ones. In any event, the fullest, most multi-faceted expression of phenology tends to be in woody perennials, which feature predominantly in this article.

The evolutionary drivers of phenology are of more than purely scientific interest. They are also of increasing interest with the accentuated adaptive pressures on plant populations imposed by climate change (e.g. Kijowska-Oberc et al. 2020), ecosystem fragmentation and the arrival of new pests and pathogens. Understanding both the evolutionary drivers and the increased pressures will help in future management decisions. An extensive literature on evolutionary drivers of phenology has focused mainly on climates, with their seasonal cycles, the topic being complicated by extreme diversity of adaptive strategies. Numerous tradeoffs arise between different features of strategies that may contribute to fitness in particular environments. Adaptive strategies for any organisms are thus highly multidimensional, being characterised by how different features interact with each other to create ecological fitness, and not by any single features. Even within a single habitat, different plant species typically vary widely in their adaptive strategies. This is obvious for co-occurring species that are evergreen or deciduous as the case may be. Less obvious, though, are some specific selective forces that shape individual strategies.

Ontogenetic phenologyis considered briefly towards the end of this article, to give perspective. It centres on how plants, as they get older and larger, undergo maturation, which is manifested in widely varying degrees (Poethig 1990; Zotz et al. 2011). It generally involves acquisition of reproductive competence, which introduces a whole suite of seasonal expression. Even vegetatively, there can be a transition from a juvenile habit to a mature one, or in some species a relatively abrupt switch (Zotz et al. 2011). Whatever the case, there can be major changes in gross morphology and tissue anatomy.

Some consideration has been given interplays between biotic factors and plant phenology. Both biotic and abiotic selective influences were considered decades ago in reviews focused on plant phenology. Rathcke and Lacey (1985), however, focused heavily on quantitative descriptors of phenology, namely timing, duration, synchrony and statistical distributions of phenological events. Van Schaik et al. (1993) emphasised on seasonal climatic drivers of phenology, with the implications for herbivores ("consumers"). Recently, in relation to the relative importance of biotic drivers of local adaptation, meta-analyses have been conducted - albeit with no specific focus on phenology. Hargreaves et al. (2020) did so for biotic effects in plants only, and Briscoe Runquist et al. (2020) for abiotic and biotic effects in plants and animals. Some trends were detected, notably in biotic influences being more important in tropical than in temperate latitudes. 
However, results were very heterogeneous and perennial plants were weakly represented. One area that has been significantly researched is seasonal phenology in relation to herbivory within the tropics (Lamarre et al. 2014). In some other cases, the research focus has been on the seasonal phenology of herbivorous insects adjusting to that of the host plant (e.g. Elzinga et al. 2007; Chuine 2010; Singer and Parmesan 2010). In a context of mammalian herbivory, Benning et al. (2018) cite a case of a plant's reproductive phenology constraining its geographic range.

Despite these considerations, the possible extent and diversity of putative biotic factors as evolutionary drivers of seasonal plant phenology appear to remain under-researched, especially with pathogens. Such factors represent the main focus of this paper. We consider the evolutionary importance of biotic interactions, involving pathogens and herbivory, with plant phenology. Main emphasis is on seasonal phenology, with brief consideration of ontogenetic phenology. While some postulated cases are cited from the literature, we offer others. Among postulated cases, involving both pathogens and herbivores, we first consider briefly the timing and synchronicity of both vegetative growth (bud burst, shoot flushing and bud set) and flowering. We then focus strongly on the complete seasonal leaf fall that characterises the deciduous habit, in relation to selective pressures imposed by pathogens and herbivores, and address the evolutionary hurdles facing shifts between the deciduous and evergreen habits. Several other cases of putative biotic drivers are also outlined. Coverage involves mainly woody perennial plants, but two cases with pasture plants are considered, along with one involving various wild herbaceous plants. As such, our coverage serves to illustrate the diversity of likely biotic interactions involving plant phenology, and the need for additional investigation, rather than any attempt at comprehensive or even systematic review. We draw heavily on close research familiarity with certain species, hoping that the value of some detailed case histories outweighs the sparseness of the coverage

In considering the evolutionary importance of biotic interactions, involving pathogens and herbivory, with plant phenology our main emphasis is on seasonal phenology. Ontogenetic phenology is considered briefly.

\section{Seasonal phenology}

We note initially some key features of seasonal phenology, in relation to cues and selective forces involving climate, as background for considering interactions with pathogens and herbivory.

Traits of seasonal phenology are often both variable and heritable within populations (e.g. Li and Adams 1993; Matziris 1994; Skrøppa and Steffenrem 2019), giving scope for evolutionary change. Nevertheless, limits to a species' phenology can still govern its geographic range (Chuine 2010), which of course may be altered by climatic change. However, our focus is on likely drivers of the phenology of populations wherever they are growing, considering vegetative and reproductive aspects separately.

\subsection{Vegetative aspect}

In the seasonal timing of vegetative shoot phenology, there are the obvious climatic drivers, reviewed in detail by Axelrod (1966). A key feature is timing of bud burst, or flushing, which typically occurs in spring in temperate climates or in some relation to wet and dry seasons in tropical or semi-tropical climates. Also typical is a close seasonal concentration and synchronisation of flushing. In temperate or cool temperate climates, optimal fitness will classically represent some balance between the advantages of flushing as soon as conditions favour growth and the safety of delaying it until after almost all threat from late (spring) frost. The period of shoot extension growth that follows flushing can be very brief, certainly in many temperate tree species, including various conifers. Often these seasons seem far shorter than the periods when climatic conditions would permit active growth, classic examples existing among the true firs (Abies spp). Complementing flushing and subsequent shoot extension are bud set associated with the cessation of elongation, and the complete shedding of foliage in deciduous species. These processes occur in late summer or autumn in temperate or cool temperate climates, but in variable relationships to dry seasons at lower latitudes.

\subsection{Reproductive aspect}

Seasonal synchronisation of flowering is often closely linked to vegetative phenology. This has several obvious benefits, apart from those incidental to optimal timing with respect to climatic factors. Among the benefits, 
close synchronisation helps assure adequate pollen when the female structures are receptive. Also, by all occurring early enough, this assures sufficient time for fruits and seeds to develop and mature before either summer drought or autumn cold disrupt such processes. Moreover, brief but differentiated flowering seasons can also provide reproductive barriers between species that are interfertile but whose hybrids may not be ecologically fit; however, such barriers have broken down in some eucalypt species grown as exotics where their flowering seasons differ from those in native habitats (Eldridge et al. 1993). This synchrony can mean very seasonal food supplies for animal pollinators, but very short seasons can be made good by other, sympatric species having differentiated flowering seasons. A further but probably very incidental benefit of flowering synchrony may be creating a brief superabundance for herbivores, which we will consider later.

Masting, namely heavy seed production in some years with little or none in between (e.g. Kelly 1994; Kelly and Sork 2002), is a phenomenon involving the timing of flowering. Its postulated biotic significance is as a means of alternating between occasional predator satiation and more frequent predator avoidance. However, it is not actually a seasonal phenomenon, nor really ontogenetic, so it is not considered further.

Timing of flowering has been reported as a minor factor in complex interactions involving transmission of pathogens by pollinators (Biere and Antonovics 1996; McArt et al. 2014), but is not considered further in this connection.

\section{Pathogens as putative drivers}

The role of pathogens as potential evolutionary drivers of seasonal phenology appears to have been especially under-researched. Cases we consider involve: potential roles of pathogens in governing the deciduous growth habit; the seasonal timing of spring flushing in a widely distributed conifer; two closely related Pinus species with overlapping distributions but markedly different seasonal timing of vegetative and reproductive processes; and an oak species in what is effectively an altitudinal transect. Briefly considered also is how pathogens can modify phenotypically some processes that are normally parts of seasonal phenology.

\subsubsection{Deciduous versus evergreen habit}

Of special note in phenology is the seasonal complete shedding of foliage that characterises the deciduous habit, versus the evergreen habit. This was reviewed by Holttum (1953) for tropical forests and Axelrod (1966) for temperate forests. These important papers exemplify most subsequent enquiry on the evolutionary drivers of deciduousness, in pointing to factors of the abiotic environment. Both authors postulated that seasonal drought was the original driver. Specifically, Axelrod postulated that this habit, having originated during the Cretaceous, was a preadaptation to cold winters that subsequently characterised high-latitude environments along with their widely fluctuating daylengths. Yet, in many harsh, high-latitude climates, with very severe winters, both deciduous and evergreen tree species co-occur. Moreover, even within some genera, notably Nothofagus in South America, both deciduous and evergreen species can grow adjacently. In adaptation to climates with severe winters there are some obvious trade-offs. The deciduous habit entails heavy seasonal turnover of biomass, but the leaves do not require investment in anatomical features needed for overwintering. This habit also allows the leaves to be photosynthetically very efficient relative to their dry matter (Reich et al. 1992). Apart from co-occurring species, sometimes close relatives, including both evergreens and deciduous ones, there are other obstacles to facile climatic interpretation. For instance, deciduousness exists among many species without severe winters (e.g. Suc 1984; Li et al. 2013). Also, there are deciduous tropical tree species that produce new foliage well before dry seasons end, which we will revisit.

For the evergreen habit, the anatomical requirements for leaves surviving winters or other seasonal stresses will also tend to make them less attractive or rewarding to herbivores in general. Such protection against herbivory is very often complemented by toxin production. All these defences, along with defences against abiotic factors, require additional investments (Loehle \& Namkoong 1987; Strauss et al. 2002; Kursar \& Coley 2003; Villar et al. 2006), or "higher construction costs" (Smith et al. 2019). However, such investments can obviate the cost of the complete seasonal turnover of foliage in deciduous plants. Also, early flushing is not crucial for evergreens to resume photosynthesis in the spring (cf Panchen et al. 2014). Osada (2020), comparing sympatric evergreen and deciduous species, found the former to have later and longer periods of 
leaf expansion. One might expect foliage toxicity to be more prevalent and more severe in evergreen species than in deciduous ones, but we have found no published survey on this question. Anecdotally, however, yews (Taxus spp) which are evergreen are both notoriously toxic and often associates of deciduous species. Within a deciduous example (Populus deltoides $\times$ P. nigra 'Robusta') a subtle, seasonal effect of seasonal decline in phenolic compounds being associated with increasing susceptibility to the leaf rust Melampsora laricipopulina Kleb. was observed by Maupetit et al. (2018). This suggests that, if phenolic compounds represent a defence mechanism, that decline reflects an energetic cost of their production and decreasing value of the protection that they confer.

While much attention given to the energetic costs and associated trade-offs in alternative strategies of deciduous or evergreen habit, little seems to have been given to the possible roles of pathogens and herbivores in generating or maintaining the deciduous habit. In relation to the evolutionary pressures imposed by both biotic and abiotic factors, we will consider also the evolutionary hurdles to be overcome in shifting from one habit to the other. Regarding deciduousness, the presence and life cycles of pathogens may play a role, and we now consider a probable example.

\subsubsection{The poplar rust case}

A clue came when two poplar (Populus ) leaf rusts, caused by Melampsora medusae Thum. and M. laricipopulina, reached Australia and thence New Zealand in 1973 (Van Krayenoord et al. 1974; Wilkinson and Spiers 1976; Spiers 1998). These fungal pathogens, between them, severely affected most of the planted poplar clones in both countries. Both these rusts spread by urediniospores (asexual spore stage) while the poplar hosts are in leaf, this spread being polycyclic with repeated cycles of infection within the season. A the start of the autumn teliospores are produced which overwinter on fallen poplar leaves and begin the sexual stage of the life cycle. Teliospores germinate in spring producing basidiospores that infect the alternate, conifer host, generally larch (Larix sp.). Infection of poplar from mid-spring begins from aeciospores, produced on the conifer. This completes the sexual stage of the life cycle, starting afresh the polycyclic seasonal build-up of infection. Where the conifer host is not present, however, some overwintering of the uredinial stage, either on persisting poplar leaves in mild climates or possibly as mycelia within dormant leaf buds, can start the build-up (Walker et al. 1974; Wilkinson and Spiers 1976; Barrès et al. 2012; Albornoz et al. 2018). In a co-evolved host/pathogen relationship involving such leaf rusts, there should be a comparatively slow buildup of infection during the growing season. However, overwintering cycles of urediniospore production would accelerate the new seasonal build-up. In New Zealand, a semi-evergreen mutant clone (cv Sempervirens) of the Lombardy poplar (Populus nigra L. cv. Italica) had been widely planted, being often favoured for orchard shelterbelts. This had originated in Chile as a somatic mutation. Its widespread presence, with the semi-evergreen habit and the inherent susceptibility to $M$. larici-populina (but not to M. medusae), exacerbated the initial rust epidemic. Where winter conditions are suitably mild to allow retention of leaves, the all-year presence of infected leaves assured a continuing supply of urediniospores, favouring a far quicker build-up of infection in the new season than would be expected from deciduous material. Aided by this quick build-up, M. larici-populina spread rapidly and widely, defoliating poplars susceptible to both rusts, while $M$. medusae unable to build up inoculum in the winter was outcompeted and remained restricted in distribution (Wilkinson and Spiers 1976). The semi-evergreen clone was very severely affected, and was soon almost eradicated, which presumably contributed to the rusts becoming less serious a few years after arriving. Other contributing factors would have included felling of trees of other severely affected cultivars, and a spontaneous proliferation of hyperparasitic and otherwise antagonistic microorganisms in phyllosphere communities on the leaf surfaces (Heather and Chandrashekar 1982).

The semi-evergreen cultivar shared the inherent susceptibility to infection with the original deciduous cultivar. That susceptibility, however, has exposed a potential danger of an evergreen habit in reducing protection from natural delays in the seasonal build-up of infection. Such a reduction can be expected to increase the level of resistance required for field fitness. That would increase selection pressures imposed by rusts, which operate alongside all the other selection pressures. Since increased selection pressure on any trait tends to reduce the possible selection intensity for other traits, that means a potential for 'selection overload'. Moreo- 
ver, the poplar rust pathosystems are very complex (e.g. Barrès et al. 2012; Persoons et al. 2014; Albornoz et al. 2018), with a potential to be very dynamic and readily destabilised.

Co-adaptation between rusts and poplars has tended to arise in climates that have severe or moderately severe winters. Thus, the mild climates of New Zealand and Chile are not the norm for the natural pathosystems. Yet these novel conditions outside climatic norms that provide an opportunity to examine the action of pathogens as evolutionary drivers influencing the persistence of deciduousness. Testing our hypothesis, and whether an evergreen poplar could ever be ecologically fit, however, faces major practical obstacles. Ideally, a population of evergreen genotypes, rather than just one, should be used for comparison with deciduous genotypes. However, there is no easy pathway to obtaining such a population. Even using the existing semi-evergreen clone would be suspect, because it might not match young seedlings, from which native poplars grow, for susceptibility to the pathogen within the growing season. Indeed, any matching of comparison material for inherent susceptibility would be challenging. Field testing would be wanted, where natural pathogens would be present. The impact of the pathogen(s) would need to be evaluated, most likely over several years as most impacts from rusts occur after repeated seasons of infection. Evaluating impact is likely to be complicated by the fact that presence of a susceptible evergreen host will likely influence disease development and impact on deciduous genotypes. Pathogen dispersal between stands could similarly complicate the picture. To manage these challenges, chemical control (or some effective but targeted biocontrol) of the pathogen(s) would need to be used to exclude rust impacts from a subset of trees. Support for our hypothesis would be obtained from the persistence of susceptible evergreen genotypes, and the relative success compared to susceptible deciduous genotypes, where the pathogen impacts are excluded from both, and the decline and eventual extinction of evergreen genotypes where pathogen impacts are not prevented.

\subsubsection{Some deciduous tropical trees}

Some deciduous tropical tree species behave very counterintuitively in producing fresh foliage before a dry season ends (e.g. Borchert and Rivera 2001; Kushwaha et al. 2015). A specific case is Faidherbia albida A. Chev. (apple-ring acacia), a widely distributed, deep-rooting tropical tree species of Africa, found with annual rainfall of 200-500 $\mathrm{mm}$. It flushes vegetatively during the dry season, but sheds its leaves during the rains (Huxley 2001), yet it flowers at the end of the wet season. Accounting for such counterintuitive behaviour is a challenge, but it is hard to see a convincing alternative to the postulate of pathogens driving a shift to deciduousness. Actual support for the postulate would come if, when such species are grown with no dry season, the new foliage suffered from pathogens. The success of such a study, however, would depend on both the presence of the appropriate pathogens and the nature of the triggers for shedding old leaves and producing new ones. An alternative driver, namely increased herbivory pressure during the wet season, seems very unlikely in these cases.

\subsubsection{Evolutionary barriers to switches of habit}

The Melampsora story raises two questions: (1) whether the influence of pathogens serves to maintain a habit, or drives switches from one to the other; and (2) if the latter, in what direction? It was long ago proposed (e.g. Holttum 1953; Axelrod 1966) that the deciduous habit arose as a defence against seasonal stresses. But, once established, it may persist, in a state of 'biotic lock-in', due to factors like the behaviour of Melampsora rusts. Answers to both questions, however, depend on the evolutionary hurdles facing the respective switches.

The evolutionary hurdles for a shift in habit will differ between the directions of switch. A related question is what factors, in what combinations, may either drive a switch or prevent one? Another question involves relationships between individual fitness and population fitness. An evolutionary switch from a deciduous to an evergreen habit might be expected to be favoured by a mild climate, imposing no stringent requirements for anatomical and physiological adjustments to abiotic factors. However, it would likely require adjustment to biotic factors. These might include enhanced morphological, anatomical or chemical defences against herbivores, or evolution of greater pathogen resistance. A mild climate, if humid, tends to favour various fungal or oomycete pathogens, creating a need for greater resistance. Thus, an evolutionary inertia may work 
against a switch to an evergreen habit. A potential corollary to that is restriction of the host's geographic range to where deciduousness does not incur a decisive competitive disadvantage.

In a co-adapted relationship between a temperate-zone evergreen host and a pathogen, the likely gains from becoming deciduous in avoiding infection pressure appear minor, especially compared with the selective and energetic costs of acquiring the habit. With a new pathogen arriving, the comparative fitness advantages and selective costs can change radically, as with Melampsora. This risk is much elevated by increasing human influences, from long-distance trade and travel.

\subsubsection{Discussion}

We are not postulating that pathogens have necessarily created a biotic lock-in of deciduousness, but rather that the evolutionary inertia may have been decisive in some cases but not others. The evolutionary outcome could likely be influenced by various factors, including details of the pathogen life cycle. Possibly relevant details include: longevity of fungal fruiting bodies, level of host specificity, and absence or presence of alternate hosts. If alternate hosts exist, whether they are obligate, and what phases of the pathogen life occur in which host, are also likely to be relevant.

The story for tropical tree species does appear to be different. The production of foliage during the dry season in some species suggests strongly that, if pathogens are a selective force, they would have driven a switch to deciduousness.

The picture concerning the general incidence of deciduousness among woody perennial taxa is mixed. Conifers, which represent the ancient taxon, are very predominantly evergreen, suggesting profound evolutionary inertia against a shift to deciduousness. One exception is the entire genus Larix, within the Pinaceae, being deciduous. The remaining exceptions are all Taxodiaceae members of the Cupressaeae/Taxodiaceae complex, namely the genera Taxodium, Glyptostrobus and Metasequoia, although T. mucronatum Ten. is semi-deciduous. They also tend to have few pathogens, along with some other taxonomically isolated species. Among angiosperms, which are evolutionarily more recent, deciduousness is far more common, in numbers of species if not in percent of total species. Even with genera, sympatric species can include both deciduous and evergreen members. This is so with Nothofagus in South America (as already mentioned), and Quercus in North America where there are semi-evergreens) and the Mediterranean basin. Overall, the general incidence of deciduousness among taxa argues against any completely overriding influence of abiotic environment ot taxonomic lineageper se .

\subsubsection{Swiss needle cast and Douglas-fir}

With native populations of Douglas-fir (Pseudotsuga menziesii(Mirb.) Franco in western north America, dates of spring bud burst show a coast-to-inland gradient from the Pacific coast. At a given elevation bud burst comes earlier the further from the coast (Campbell and Sugano 1979). This has been observed not only in situ but also in common-garden experiments, ruling out a simple effect of cooler coastal temperatures caused by the cold ocean current. One possible reason is that coastal populations have a longer humid season in which to complete vegetative growth and cone ripening, especially compared with more easterly populations where summer drought starts earlier (cf Campbell and Sorensen 1978). Another possible factor may be less insolation early in spring. Both factors might reduce the advantages of early bud burst. Yet another possibility, not mutually exclusive, is that later bud burst escapes the worst of the seasonal hazard, created by humidity, of infection by foliage pathogens. Of such pathogens the most prominent is Phaeocryptopus gaeumannii (T.Rohde) Petrak, cause of Swiss needle cast (Boyce 1940; Mulvey et al. 2013), which is most aggressive in the humid coastal climates. Given the postulated selection pressure imposed by the pathogen, one might expect fog-belt Douglas-fir grown in very mild climates without the pathogen to show a genetic shift to earlier bud burst. However, any such study would both be long-term and face the difficulty of finding anywhere that will remain free of the pathogen. Chemical control of the pathogen would need to be long-term and is expensive, and could fail through the pathogen evolving resistance.

\subsubsection{Two Pinusspecies}


Two closely related coastal California pine species appear to be another case in point. They are Pinus radiat a D.Don (either Monterey pine or radiata pine) and P. muricata D.Don (bishop pine or muricata pine). They have overlapping (but almost entirely allopatric) geographic distributions. Pinus radiata ranges discontinuously from $28-37 \mathrm{degN}$ and $P$. muricata discontinuously from $31^{1} / 2^{-}-41 \operatorname{degN}$. Pinus radiata has a very long, opportunistic growing season, being able to make growth all year if temperatures permit, which evidently accounts for a very fast growth potential (e.g. Burdon 2001; Burdon et al. 2017). By comparison.P. muricata makes minimal shoot elongation during winter, with apical buds remaining sealed, and is slower growing. Correspondingly, it has a later pollination season. These species are naturally challenged by strongly overlapping sets of pathogens, notably ones causing needle casts and shoot galls.

\subsubsection{Needle casts}

Pinus radiata, when grown in the British Isles, is very subject to a foliage disorder called "yellows" (Lally and Thompson 2000; Fennessy et al. 2012). This is very severe needle cast, which was eventually linked to the fungus Cyclaneusma minus (Butin) DiCosmo after problems with false negative isolations. The disease occurs after long spells of mild cloudy weather in winter and early spring which mean very low insolation at such latitudes. Similar needle casts have occurred in New Zealand, associated with prolonged very wet and mild winter weather. One of these has been attributed to C. minusemerging from latent pathogen status to cause "spring needle cast". Another, called "physiological needle blight", has been unexplained but is now suspected to have been caused by the oomycetePhytophthora kernoviae Brasier, Beales \& S.A. Kirk (McDougal and Ganley 2021). Yet another, "red needle cast", has been associated mainly with Phytophthora pluvialis Reeser, Sutton \& Hansen and to a lesser extent with P. kernoviae (Fraser et al. 2020). Such weather, with temperatures allowing growth but with low insolation restricting photosynthesis, is likely to deplete the carbohydrate reserves that would help the host resist pathogens. By comparison, the more winter-dormant Guadalupe Island provenance of Pinus radiata is less prone to yellows (Fennessy et al. 2012) than cultivated $P$. radiata stocks of mainland California origin. Also, northern populations (Lat. $>38 \mathrm{degN}$ in California) of $P$. muricata, which is much more winter-dormant, are far less subject to such needle casts. While this comparison involves both species as exotics, rather than in natural habitats, it suggests that pathogen pressure can favour winter quiescence despite winter temperatures that permit active growth. That said, $P$. radiatamust suffer very severe needle cast before it is outgrown by $P$. muricata (Ades et al. 1992; Burdon and Low 2020). In the northern populations of $P$. muricata, however, selective pressures imposed by such foliage pathogens may have favoured winter dormancy. Winter cold in their coastal environments seems unlikely to be a strong selective force, especially as $P$. radiata (of origin $36^{1} / 2^{-}-37 \mathrm{degN}$ ) is notable for growing-season frost tolerance (ca - 6degC). This tolerance exceeds that of material derived from one such $P$. muricata population (Lat. 39-391/2 $\operatorname{degN}$ ) (Menzies \& Holden 1981).

\subsubsection{Western gall rust}

A prominent shoot pathogen affecting pines within and beyond the natural ranges of $P$. radiata and $P$. muricata isEndocronartium harknessii (J.P. Moore) Hirats. which causes western gall rust (Old 1981; Ramsfield et al. 2007). It infects soft, elongating shoots during spring to early summer. In certain years, when cool, moist conditions persist during the infection season, abundant 'wave year' infection can occur. We suggest that the late flushing in the northern populations of $P$. muricata, while it may reduce growth potential, reduces exposure to infection hazard, in a trade-off. By comparison P. radiata, with its earlier shoot flushing, is vulnerable to infection over a longer season, although its dryer habitats, all south of San Francisco Bay, mean that infection hazard is lower. The fitness advantage of the greater growth potential of $P$. radiata resulting from the longer growing season, maybe with some enhanced genetic resistance, evidently outweighs the fitness cost of the associated extension of the infection season in its habitat. The fitness cost of susceptibility is likely mitigated by susceptibility being largely confined to young trees (Old et al. 1986) which often arise at high density from stand-replacing fires. Selection for resistance, with gall rust infections affecting competitive ability, thereby contributing to the natural self-thinning, would represent essentially 'soft' (density-dependent) selection.

\subsubsection{Discussion}


There is thus reason to suspect that both foliage pathogens and western gall rust have imposed selective pressures contributing to the comparative seasonal phenology of $P$. radiata and northern populations of $P$. muricata. Problematically, however, this interpretation does not account for the flushing and pollination dates of the southern populations of P. muricata $(<37 \mathrm{degN})$. Brown (1966), recording pollination dates, which are also a reliable proxy for flushing dates, observed later pollination than in these populations than in $P$. radiata, although those populations flush earlier than the northern populations. These populations are also acutely susceptible to foliage disease (Ades et al. 1992; Burdon and Low 2020) but are naturally exposed to low disease hazard. Brown's observations were made in an essentially common-garden situation near Canberra, Australia. There is only one location, Monterey, where the two species naturally co-occur, and different pollination dates are putatively an adaptive crossing barrier there. Later pollination than in $P$. radiata in other southern populations of $P$. muricata, however, is not so readily explained, although it did not closely fit a clinal pattern. Moreover, the coolness of the trial site, near Canberra, may have distorted the comparative phenology of the southern populations.

\subsection{4}

Quercus petraea

Flushing date can also involve a trade-off in defences between climatic and biotic factors. An example has been documented for sessile oak (Quercus petraea (Matt.) Liebl.) in the Pyrenees mountains (DesprezLoustau 2010; Dantec et al. 2015). The abiotic factor is late spring frosts, and the biotic factor is oak powdery mildew (caused byErysiphe quercicola Takam. et al.). Late flushing is a defence against the frosts, whereas early flushing helps protect against the mildew. At higher altitudes, where late frost represents the main adaptive hazard, late-flushing genotypes are favoured. At lower altitudes, which are more conducive to the powdery mildew but less subject to late frosts, early-flushing genotypes are favoured. Indeed, the greatest incidence and severity of disease occur at intermediate altitudes. With the trade-off meaning no closely defined or geographically broad optimum for flushing date, the large tree-to-tree variability in flushing date, especially at lower altitudes (Alberto et al. 2011), is not surprising. Some validation of the interpretation could in principle be obtained by studying the impact of chemical control of the pathogen, but such a measure faces prohibitive practical difficulties.

\subsubsection{Pathogen-induced simulations of phenology}

In addition to putative cases of pathogens operating as selective influences on natural seasonal phenology, pathogens can exert more direct phenotypic effects on features of the underlying seasonal phenology of the hosts. Classically, foliage infection is a widespread cause of premature leaf fall. Such cases generally entail hosts responding to infection by abscission of foliage or foliage structures. The responses can be adaptively significant, as defence mechanisms for the hosts (Fraser et al. 2016). In some cases, shedding infected foliage may remove inoculum, as well as possibly denying a pathogen further sustenance. This appears to be so in the case (already mentioned) of needle cast associated with Cyclaneusma minus in pine species. In some other cases, prompt shedding of foliage can prevent dangerous spread of the pathogen within the host. With white pine blister rust, caused by Cronartium ribicola J.C.Fisch., prompt abscission of infected fascicles can serve as an effective resistance mechanism in both Pinus monticola Douglas ex D.Don (Hoff and McDonald 1971) and $P$. armandii Franch (Hoff and McDonald 1975). The effect of a plant-pathogen interaction at the level of a plant may differ from the impact on individual infected tissues; for example, powdery mildew infection of pedunculate oak ( $Q$. robur $)$ leaves resulted in earlier senescence, but higher average infection promoted later autumn phenology in those seedlings overall (Mutz et al. 2021). While infection-related foliage abscission typically shows seasonality governed by infection and/or sporulation cycles of the pathogens, along with seasonal fluctuations in the host's carbon economy, this does not mean that the abscission is intrinsic to the host's seasonal phenology.

In contrast to infection-triggered foliage abscission, infection of larch (Larix) foliage by Hypodermella laricis Tuboef can stop natural abscission, thereby keeping the foliage as a continuing source of inoculum (Cohen 1987). 


\subsection{Herbivory as a putative driver}

\subsubsection{Woody perennials}

It has been noted that the timing synchronisation of seasonal flushing can represent a balance between the advantages of flushing as soon as conditions favour growth and the safety of delaying it until after almost all threat from climatic damage. In temperate zones, where seasons are defined primarily by temperatures, the classic danger is late (spring) frost. However, it is unclear whether close synchronisation of flushing is necessarily an adaptive consequence of meeting that balance. An alternative interpretation is that close synchronisation of bud burst and shoot and leaf extension means a brief period of 'predator satiation' or 'predator swamping' (cf Emlen 1966; Molles 2002) This would represent the period of maximum food value for browsers or other herbivores, after which the food value declines sharply. That decline, if it helps to limit the herbivore carrying capacity of an ecosystem, also represents a feedback mechanism to reduce browsing pressure. That, in turn may reduce the ecological importance of other defences against herbivory. A question arising with deciduous woody perennials, is whether, or how much, any such predator-satiation defence may be incidental to the advantage of quick and complete seasonal restoration of photosynthetic capacity The Quercus petraea / powdery mildew case, with tree-to-tree variation in flushing date, suggests that it is not entirely so.

With evergrees, in which complete seasonal restoration of photosynthetic capacity is not an issue, the expected premium for earliness of flushing is less. In this connection, while apparently not documented, the very brief flushing periods of some conifers, notably some firs (Abiesspp\} in very mesic habitats, strongly suggests a predator satiation strategy. Proving the postulate, however, is far more difficult than proposing. But there would be scope for documenting the phenology in relation to climate and moisture status, which could provide evidence against a simple climatic explanation.

Synchronisation of flowering has its own advantages, for efficiency of pollination, but it can also create a brief superabundance for herbivores, This could be another 'predator satiation' situation (cf Emlen 1966; Molles 2002), but Ims (1990) concluded that for this to operate the reproductive synchrony needs to spread across subpopulation units. Similarly, synchrony may militate against a build-up of pathogens that specialise on reproductive structures.

For the tropics, where seasonal effects are often dominated by wet or dry seasons rather than temperatures, the flushing behaviour can be more complicated than in temperate regions. There, the likely role of herbivory as a phenotypic driver has attracted more attention. Lamarre et al. (2014) report a study, and cite a number of others, of "synchrony of leaf production" in relation to herbivory. The situation represents widespread operation of predator satiation within the tropics. The story, however, can be more complicated. Aide (1992) documents a case of a woody shrub flushing outside the wet season, at a time when herbivore density is low, in 'herbivore escape'. But that species also has brief and intensive flushing and flowering, which is consistent with an element of predator satiation. One may suggest that in herbivore escape the species benefits from an outlier status. Such a status can occur among the typically numerous woody species of tropical forests. In this connection, Bagchi et al. (2014) have documented how "negative density dependent" selection pressures from pathogens can tend to favour high species diversity.

\subsubsection{Non-woody plants}

Outside woody perennials trees, three cases are adduced for herbaceous plants, two for pasture plants, and one for a collection of species in a Mediterranean climate. In one pasture-plant case, the seasonal phenology, seemingly driven by climate, may actually be driven largely by biotic factors in conjunction with climate. Key aspects of pasture-plant phenology are seasonality of forage growth and flowering. An extended growing season, meaning extended forage production, is widely sought by plant breeders. However, there is classically a trade-off between a long growing season and the persistence that avoids a need for frequent sowings to ensure sward renewal.

\subsubsection{Medicago}


Cold tolerance is typically associated, among populations, with level of winter dormancy, suggesting that active winter growth is physiologically incompatible with cold tolerance. Yet Daday (1964) observed otherwise. He studied geographic races of Medicago sativa L. (lucerne or alfafa). Among the races, he found the expected picture of a close association between level of winter dormancy and cold tolerance, admittedly not with severe winters. But, in the F2 and F3 generations of an interpopulation diallel cross that association broke down. This independence of inheritance of the two traits conflicted strongly with accepted doctrine, yet no attempt to ascertain its underlying evolutionary significance appears to have been published. We postulate that the observed winter dormancy was in large measure a defence against browsing pressure, rather than being a directly climatic adaptation. Grazing pressure would be intense in winter, and very depleting of the plants' resources if they were making active growth, presumably leading to selection for winter dormancy. With severe winters, however, dormancy would likely be physiologically obligate, but that would not preclude breeding to extend autumn growth (Castonguay et al. 2006). Our hypothesis could be experimentally probed by studying the effect of winter grazing pressure on persistence of plants that maintained varying levels of winter growth. With suitable material available that should be readily feasible. Assembling suitable material might be a challenge, and an area of ground would need to be available. Actual grazing would require livestock, but grazing might be simulated.

\subsubsection{Pasture grasses}

In the other case involving pasture plants, namely forage grasses, a biotic driver of phenology has been long recognized, at least implicitly. A key phenological trait is the heading season, involving the seasonal timing and duration of seed-head development.

Late and brief heading and a semi-prostrate habit are features of persistent 'pasture type' cultivar strains, bred from material with an ancestral history of adaptation to intense grazing (e.g. Charles 1961). By contrast, 'hay type' strains do not have the same history of adaptation to grazing. They have earlier and longer heading seasons and a more erect habit, and much less sward persistence.

\subsubsection{Other plants}

Much more recently, Waterton and Cleland (2016) studied six local and six non-local plant species grown in a common Californian Mediterranean climate where two species of rabbit applied herbivory pressure. In the absence of the herbivores early seasonal commencement of growth (shown by the non-local species) conferred a productivity advantage, but with herbivory delayed commencement was associated with an advantage. Thus, a delay was evidently a defence against herbivory, in a classic trade-off between defences and growth potential (cf Loehle \& Namkoong 1987; Strauss et al. 2002).

\section{Ontogenetic phenology}

Apart from the progression with size and/or age to reproductive competence, the process of maturation can entail radical differences between juvenile and adult habits, in a phenomenon called heteroblasty. This is common and often very pronounced in the New Zealand flora (Greenwood and Atkinson 1977). Elsewhere, less extreme differences between juvenile and adult habits are generally the norm for woody perennials. Even vegetatively, maturation can bring some changes in seasonal phenology, very often in a progressively stronger expression of the seasonal phenology (e.g. Wareing 1958; Norskov-Lauritsen 1963; Burdon 1994).

\subsection{New Zealand flora}

The heteroblasty in various New Zealand trees and shrubs has been postulated as a defence against vertebrate herbivory (Greenwood and Atkinson 1977). Specifically, various such plant species have a juvenile habit with a tangle of thin, wiry stems bearing very small leaves. This habit is seen as being unrewarding for the large, flightless birds that were the ground-dwelling browsers, or else resilient to browsing damage. Despite controversy, and difficulty of proof because those browsers are extinct, definite support for the postulate has been obtained. In a neighbouring island flora, with closely related taxa but historically lacking those birds, there is not the same heteroblasty (Greenwood 1992; Burns and Dawson 2009). Other, if less striking cases of heteroblasty conferring defences or resilience against ground-dwelling herbivores include the production 
of sharp spines on foliage or stems during a juvenile phase. Seedlings of the apple tree are a well-known example of spines being confined to the juvenile phase.

\subsection{Two pines}

In the main landmasses mammals are typically the main ground-dwelling browsers. While extreme heteroblasty is seldom evident as it is in New Zealand, there are cases where ontogenetic phenology can be interpreted in terms of changes in both palatability and browse resilience.Pinus radiata is an example. In it, the juvenile to adolescent habit is bushier and more intensively branched than the adult habit (Burdon et al. 2017), and resilience to browsing is high. The adult habit, however, is associated with greater palatability to ground-dwelling browsers and less resilience. This is notoriously evident in adult-phase scions grafted for seed orchards onto small seedlings, the scions attracting far more deer browsing than seedlings. There is evidently a trade-off of resistance or resilience to browsing against pathogen tolerance. Juvenile material is more susceptible to some pathogens, notably Endocronartium harknessii (Moore) Hirats.) which causes western gall rust (Old et al. 1986), andDothistroma septosporum (Dorog.) M. Morelet (syn. D. piniHulbary) (Burdon et al. 2017). Losses of some individual seedlings to pathogens, directly or through impaired competitive ability in the case of western gall rust, as part of density-dependent selection, may not impair population fitness in the thickets of regeneration that often occur naturally. However, another advantage of a juvenile phase can lie in how strongly a longer growing season (cf Norskov-Lauritsen 1963) can contribute to growth potential while tree growth is still partly exponential. At least one other pine, $P$. taeda L., shares the feature of being susceptible to an important gall rust pathogen, Cronartium fusiforme Hedgcock et Hunt ex Cummins, in young trees rather than later (Powers et al. 1981).

\subsection{Eucalyptus nitens}

While only incidentally reported as such, Eucalyptus nitens(H.Deane et Maiden) Maiden is a case involving a combination of strong ontogenetic phenology and both herbivory and pathogen attack. This species has major geographic (provenance) variation in the duration of juvenile foliage production (Pederick 1979). The adult phase is subject to insect herbivory, while the juvenile phase is very subject to a foliage disease (Johnson and Wilcox 1989). Provenance variation evidently reflects the comparative selective pressures imposed by insect pests and pathogens in respective habitats. Thus, provenances with persistent juvenile characteristics, while enjoying longer protection against insect herbivory, are vulnerable to foliage disease with warm, humid summers. Conversely, those provenances with a brief juvenile phase, while less vulnerable to foliage disease are more so to insect herbivory.

\section{Individual and population fitness and some ramifications}

Relationships between individual and population fitness in this connection can be problematic. Population fitness depends not just on the metric values for the fitness traits in its habitat which determine individual fitness, but also on the amount of heritable variation for those traits. In the poplar case, key adaptive traits in the wild would inlude pathogen resistance, timing of seasonal growth, and the reproductive potential that allows genetic selection to operate. Thus, the impact of some ill-adapted segregants can be outweighed by a concurrent incidence of segregants that excel their parents' fitness, since the latter contribute most to the parentage of the next generation. However, with pathogens involved, population fitness can be complicated by the nature of infection processes. With a 'polycylic' pathogen, there can be both reinfection from within the host individual and cross-infection between individuals. For instance, where pathogens impair fitness, an individual becoming deciduous gains little or no protection if the population remains evergreen and can thereby provide a continuous supply of inoculum. In this way, becoming deciduous is unlikely to be advantageous, unless either this results in asynchrony between the window of host susceptibility and presence of inoculum or individuals are too sparse to favour cross-infection. An individual becoming evergreen, however, might impair the fitness of the rest of the population through producing a continuous supply of inoculum, unless it suffers so badly from internal reinfection as to incur selective elimination. To meet that condition, internal reinfection would presumably need to predominate strongly over cross-infection between individuals, which may be common with polycyclic infection. 
Becoming evergreen could require evolution of enhanced pathogen resistance and/or some more direct fitness advantage of the habit. Natural selection for resistance may be limited by 'selective opportunity cost' whereby the fitness gains from additional resistance are in trade-off with the fitness gains from responses to other selective pressures. Some of those gains, it may be noted, will be needed to make good the decay of nonadditive genetic components of fitness that occurs upon sexual reproduction. Given the dynamic nature of biotic interactions, along with pathogen mutations, natural selection for ecological fitness can be expected to entail a "red queen" model (Van Valen 1973) requiring endless genetic shifts to maintain fitness. With longlived perennials, however, such shifts may occur most readily within generational cohorts, during lifespans. With the complex and highly dynamic poplar rust pathosystem, poplar plantations have proved notoriously vulnerable to pathotype mutations (e.g. Persoons et al. 2014). Such plantations are typically monoclonal, which makes them convenient to produce and manage. Present understanding of pathosystems suggests that natural populations of poplars, reproducing by seed, might be expected to be more resilient towards the rusts. However, fully functioning natural populations, which would provide a good basis for comparison, are becoming increasingly scarce.

It must be noted that the biotic vulnerability of poplar plantations, based on species that are Melampsora hosts, contrasts with the biotic resilience of natural stands of American (or trembling) aspen (Popiulus tremuloides Michaux) which are typically monoclonal (Latutrie et al. 2015). The aspen, with different pathogens, is evidently involved in very different pathosystems.

\section{Pre-adaptive relationships?}

As indicated above, seasonal timing of phenological events may serve as defence against pathogens through avoidance of infection seasons while the plant is vulnerable. Alternatively, the timing may be a source of vulnerability. This seems evident in some cases of freshly introduced pathogens, rather than in historically co-evolved cases. With Dutch elm disease, caused by ascomycete fungi Ophiostoma spp, early bud burst and flushing, while possibly incurring climatic vulnerability, can evidently avoid the height of the infection season (Ghelardini \& Santini 2009). With sudden oak death, caused by Phytophthora ramorum Werres et al., host vulnerability has been linked to timing of bud burst and onset of cambial activity in the hosts (Dodd et al. 2008). Similarly, the pathogen Austropuccinia psidii (G. Winter) Beenken, a rust affecting a wide range of hosts in the Myrtaceae that has invaded parts of Asia and the Pacific, can only infect actively flushing host tissues (Beresford et al. 2020). In each case, invasive pathogens appear likely to place strong selective pressures on the phenology of native host populations, and understanding the potential for adaptive responses appears to be worth further study.

\section{Concluding}

We propose that pathogens can be strong evolutionary drivers of seasonal phenology, especially in respect of deciduousness. This appears to be largely novel. Some evidence is given for our proposal for deciduousness in a temperate zone. In the tropics, the proposal is made for want of any other satisfactory explanation. Other examples are given of how pathogens may influence seasonality of shoot flushing, where simple climatic explanations seem inadequate. We suggest that evolutionary barriers can operate against a shift from a deciduous to an evergreen habit in some temperate-zone cases.

For herbivory we have proposed that predator satiation may operate as an evolutionary driver in addition to purely climatic adaptation to the occurrence of winters. Herbivory is also proposed as an evolutionary constraint on growing or flowering seasons. For the tropics, where climates are largely characterised by wet and dry seasons, predator satiation has already been implicitly identified as a quite common evolutionary driver of seasonal phenology.

Ontogenetic phenology appears strongly influenced evolutionarily by biotic factors, including both herbivory and pathogens.

How a particular situation plays out will depend on many factors, notably the general climatic context and the constraints it imposes (along with other environmental factors), and the nature of biotic pressures, viz 
pathogens and/or herbivory. More specifically, the factors for pathogens involve the reproductive biology of pathogens including seasonality; the host plant ecology, in the scale from highly gregarious to essentially solitary; and the genetic systems of both host and pathogens. For herbivory, they include the life cycles and seasonal abundance of insects, along with the nature and abundance of vertebrate browsers. Not to be ignored are interactions with other plants in the ecosystem and among herbivores.

Influences of climate are both direct and indirect, the latter category involving how much climate favours pathogens and herbivores. With pathogens, there is the classic 'triangle' of interactions involving host, pathogen and the environment, so the direct and indirect evolutionary influences are in some degree interdependent. With the poplar/Melampsora pathosystem, a direct influence of a climate that is milder than the native one may favour an evergreen habit. But the indirect influence, through the effect of the same climate on the pathogen, is likely to militate against that shift. Often, however, the evolutionary pressures from climatic and biotic factors would be mutually reinforcing, as in the Medicago case.

In calling for a broad evaluation of biotic factors as evolutionary drivers (or co-drivers) of plant phenology, the coverage is preliminary and selective, representing an alert to the topic. Even a more systematic literature review would still require interpretation of individual cases. Challenges certainly exist in such evaluation. To identify likely cases of biotic drivers, we consider it appropriate to look largely to those who are closely familiar with individual plant species and their ecology. Then detailed review and analysis of available evidence is needed, but interpretation in individual cases may still be problematic. From there, the general postulate of biotic influences will need to be carried forward into hypotheses that are observationally or experimentally testable. While woody perennials have provided tantalising case histories, they can also pose major logistical challenges in testing hypotheses.

\section{References}

Ades, P. K., Simpson, K. G., Eldridge, K. G. \& Eldridge, R. H. (1992). Genetic variation in susceptibility to Dothistroma needle blight in provenances and families of Pinus muricata . Canadian Journal of Forest Research, 22 , 1111- 1117.

Aide, T. M. (1992). Dry season leaf production: an escape from herbivory. Biotropica, 24 , 32- 537.

Albert, L. P., Restrepo-Coupe, N., Smith, M. N., Wu, J., Chavana-Bryant, C., Prohaska, N., Taylor,T.C., Martins, G.A., Ciais, P., Mao, J., Arain, M.A., Li, W., Shi, X., Ricciuto, D. M., Huxman, T. E., McMahon, S. M., \& Saleska, S. R. (2019). Cryptic phenology in plants: Case studies, implications, and recommendations. Global Change Biology,25, 3591- 3608.

Alberto, F., Bouffier, L., Louvet, J.-M., Lamy, J.-B., Delzon, S., \& Kremer, A. (2011). Adaptive responses for seed and leaf phenology in natural populations of sessile oak along an altitudinal gradient. Journal of Evolutionary Biology. 24, 1442- 1454.

Albornoz, M. V., Lolas, M., Verdugo, J. A., Ramirez, C. C. (2018). Identification of virulences in the rust fungus Melampsora larici-populina occurring in Chile. Plant Disease, 202 , 2001- 2004.

Axelrod, D. I. (1966). Origin of deciduous and evergreen habits in temperate forests. Evolution, 20 , 1- 15

Bagchi, R., Gallery, R. E., Gripenberg, S., Gurr, S. J., Narayan, L., Addis, C. E., Freckleton, R. P., \&. Lewis. O.T. (2014). Pathogens and insect herbivores drive rainforest plant diversity and composition. Nature , $506,85-88$.

Barres, B., Halkett, F., Dutech, C., Andrieux, A., \& Pinon, J. (2012). Genetic structure of the poplar rust fungus Melampsora larici-populina : Evidence for isolation by distance in Europe and recent founder effects overseas.Infection, Genetics and Evolution, 8 (5), 577- 587. https://doi.org/10.1016/j.meegid.2008.04.005Get rights and content

Benning, J. W., Eckhart, V.M., Geber, M.A., \& Moeller, D.A. (2018). Biotic interactions limit the geographic range of an annual plant: herbivory and phenology mediate fitness beyond a range margin.bioRevxiv preprint 
doi: https://doi.org/10.1101/300590.

Beresford, R. M., Shuey, L. S., \& Pegg. G. S. (2020). Symptom development and latent period of Austropuccinia psidii (myrtle rust) in relation to host species, temperature, and ontogenic resistance. Plant Pathology , 69 , 484- 494 .

Biere, A., \& Antonovics, J. (1996). Sex-specific costs of resistance to the fungal pathogen Ustilago violacea (microbotryum Violaceum ) in Silene alba . Evolution , 50 (3), 1098- 1110. https://doi.org/10.1111/j.15585646.1996.tb02350.x

Borchert, R., \& Rivera G. 2001). Photoperiodic control of seasonal development and dormancy in tropical stem-succulent plants. Plant Physiology , 31 (4), 213-221.

Boyce, J. S. (1940. A needle-cast of Douglas Fir associated with Adelopus gaumannii [Rohde]. Phytopathology ,30, 649-659.

Briscoe Runquist, B. D., A. J. Gorton, A.J., Yoder, J. B., Deacon, N.J., Grossman, J.J.,Kothari, S., Lyons, M. P., Sheth, S.N., Tiffin, P., \& Moeller. D. A. (2020). Context dependence of local adaptation to abiotic and biotic environments: a quantitative and qualitative synthesis.American Naturalist, 195 , 412- 431.

Brown, A. G. (1966). Isolating barriers between Californian closed-cone pines. MSc thesis, University of Sydney, Australia.

Burdon, R. D. (1994). Annual growth stages for height and diameter inPinus radiata. New Zealand Journal of Forestry Science ,24, 11- 17

Burdon, R. D. (2001). Pinus radiata . In F. T. Last, ed. Ecosystems of the world, vol. 19, Tree crop ecosystems, pp. 99- 191, Amsterdam. The Netherlands, Elsevier.

Burdon, R., \& Low. C. (2020). The muricata pine story - A roller coaster. New Zealand Tree Grower , 41 (2) , 35- 38 (May 2020).

Burdon, R. D., Libby, W.J., \& Brown. A. G. (2017). Domestication of radiata pine. Springer International. $\mathrm{XXXV}+480 \mathrm{p}$.

Burns, K. C., \& W. Dawson. J. W. (2009). Heteroblasty on Chatham Island: a comparison with New Zealand and New Caledonia. New Zealand Journal of Ecology , 33 , 156- 163.

Campbell, R. K., \& Sorensen, F. T. (1978). Effect of test environment on expression of clines and on delimitation of seed zones in Douglas-fir. Theoretical and Applied Genetics, 51 , 233- 246.

Campbell, R., \& Sugano, A. L. (1979). Genecology of bud burst phenology in Douglas-fir. Botanical Gazette , $140,223-231$.

Castonguay. Y., Laberge. S., Brummer, E. C., \&. Volenec, J.J. (2006). Alfafa winter hardiness: A research retrospective and integrated perspective. Advances in Agronomy, 90 , 203- 265.

Charles, A. H. (1961). Differential survival of cultivars ofLolium, Dactyli s and Phleum . Grass and Forage Science, $16,69-79$.

Chuine, I. (2010). Why does phenology drive species distribution? Philosophical Transactions of the Royal Society B , 365, 3149- 3160 .

Cohen, L. I. (1987). The pathology of Hypodermella laricis on larch, Laricis occidentalis . American Journal of Botany ,54, 118- 124 .

Daday, H. (1964). Genetic relationship between cold hardiness and growth at low temperatures in Medicago sativa . Heredity ,19, 173- 179. 
Dantec, C. F., H. Ducasse, H., Capdevielle, X., Fabreguettes, O., Delzon, S., \& Desprez-Loustau, M.-L. (2015). Escape of spring frost and disease through phenological variations in oak populations along elevation gradients. Journal of Ecology, 103 , 1044- 1056.

Desprez-Loustau, M.-L., Vitasse, Y., Delzon, S., Capdevielle, X., Marcais, B., \& Kremer, A. (2010). Are plant pathogen populations adapted for encounter with their host? A case study of phenological synchrony between oak and an obligate fungal parasite along an altitudinal gradient. Journal of Evolutionary Biology ,23, 87- 97.

Dodd, R. S., D. Huberli, D., Mayer, W., Harnik, T.Y., Afzal-Rafii, Z., \& Garbelotto M. (2008). Evidence for the role of synchronicity between host phenology and pathogen activity in the distribution of sudden oak death canker disease. New Phytologist, 179 , 505- 514.

Eldridge, K., Davidson, J., Harwood, C., \& van Wyk, G. (1993). Eucalypt domestication and breeding. Oxford, UK, Clarendon Press, xix +288 p.

Elzinga, J., Atlan, A., Biere, A., Gigord, L., Weis, A. E., \& Bernasconi, G. (2007). Time after time: flowering phenology and biotic interactions. Trends in Ecology and Evolution, 22 (6), 432- 439.

Emlen, J. M. (1966). The role of time and energy in food performance.American Naturalist, 100, 611- 617.

Fennessy, J., Doody, P., \& Thompson, D. (2012). A review of tree improvement programmes in Ireland historical developments, current situation and future practice. Irish Forestry, 69 , 194- 203.

Fraser, S., J. Martin-Garcia, J., Perry, A., Kabir, M.S., Owen, T., Solla, A., Brown, A. V., Bulman, L. S., Barnes, I., Hale, M. D., Vasconcelos, M. W., Lewis, K.J, Doğmuş-Lehtijarvi, H.T., Markovskaja, S., Woodward, S., \& Bradshaw R. E. (2016). A review of Pinaceae resistance mechanisms against needle and shoot pathogens with a focus on the Dothistroma -Pinusinteraction. Forest Pathology , 46 , 453- 471.

Fraser, S., Gomez-Gallego,M., Gardner, J., \&. Bulman. L. S. (2020). Impact of weather and season on sporulation of Phytophthora pluvialis and Phytophthora kernoviae. Forest Pathology ,50 (2) , e12588. March 2020.

Ghelardini, L., \& Santini, A. (2009). Avoidance by early flushing: a new perspective on Dutch elm disease research. iForest - Biogeosciences and Forestry, 2, 143- 153.

Greenwood, R. M. (1992). Some differences between plants of the Chatham Islands and the New Zealand mainland. New Zealand Journal of Ecology, 16 , 51- 52.

Greenwood, R. M., \&. Atkinson, I. A. E. (1977). Evolution of divaricating plants in relation to moa browsing. Proceedings, New Zealand Ecological Society, 24, 21- 33.

Hargreaves, A. L., Germain, R. W., Bontrager, M., Persi, J., \& Angert, A. L. (2020). Local adaptations to biotic interactions: a meta-analysis across latitudes. American Naturalist , 195 , 395- 411.

Heather, W. A., \& Chandrashekar, M. (1982). Evolutionary, epidemiological and ecological implications of form of resistance in Populus spp to Melampsora leaf rust. Australian Forest Research , 12 , 231- 244.

Hoff, R. J., \& McDonald, G. I. (1971). Resistance to Cronartium ribicola in Pinus monticola ; short shoot fungicidal reaction. Canadian Journal of Botany , 49, 1235- 1239.

Hoff, R. J., \& McDonald, G. I. (1975). Hypersensitive reaction of Pinus armandii caused by Cronartium ribicola .Canadian Journal of Forest Research , 5 , 146- 148.

Holttum, P. E. (1953). Evolutionary trends in an equatorial climate.Society of Experimental Biology Symposium , 7 , 159- 173 .

Huxley, P. A. (2001). Multipurpose trees: Biological and ecological aspects relevant to their selection and use. In F. T. Last, ed. Ecosystems of the world, vol. 19, Tree crop ecosystems. Amsterdam, The Netherlands, Elsevier, pp 19- 74 . 
Ims, R. A. (1990). On the adaptive value of reproductive synchrony as a predator-swamping strategy. American Naturalist, $\mathbf{1 3 6}$, 485- 498.

Johnson, G. R., \& Wilcox, M. D. (1989). Eucalyptus species trials on pumiceland. New Zealand /Journal off Forestry ,34 (1), 24- 27.

Kelly. D. (1994). The evolutionary ecology of mast seeding. Trends in Ecology and Evolution, 9 (12), 465-470.

Kelly, D., \& Sork, V. L. (2002).Mast Seeding in Perennial Plants: Why, How, Where? Annual Review of Ecology and Systematics . 33 (1), 427- 447. doi: 10.1146/annurev.ecolsys.33.020602.095433.S2CID 31807259.

Kijowska-Oberc, J., Staszak, A. M., Kamiński, J., \& Ratajczak, E. (2020). Adaptation of Forest Trees to Rapidly Changing Climate.Forests, 11 , 123. https://doi.org/10.3390/f11020123

Kursar, T. A., \& Coley, P. D. (2003). Convergence in defense syndromes of young leaves in tropical rainforests. Biochemical Systematics and Ecology, 31, 929- 949.

Kushwaha, C. P., Tripathi, S. K., \&. Singh, K. P. (2015). Diversity of leaf deciduousness in important trees of dry tropical forest.In Tripathi, S. K. ed. Biodiversity in tropical ecosystems. New Delhi, Today and Tomorrow's Printers and Publishers, pp. 177- 189

Lally, M. \& Thompson, D. (2000). Monterey pine: the New Zealand "wonder tree" - does it have a role in Irish forestry. Coillte Research and Information Note 21, 4 p.

Lamarre, G. P. A., Mendoza, I., Fine, P. V. A., \& Baraloto, C. (2014). Leaf synchrony and insect herbivory among tropical tree habitat specialists. Plant Ecology 215, 209- 220.

Latutrie, M., Mérian, P., Picq, S., Bergman, Y., \& Tremblay, F. (2015) The effects of genetic diversity, climate and defoliation events on trembling aspen growth performance across Canada. Tree Genetics 83 Genomes, 11, 96. https://doi.org/10.1007/s11295-015-0925-3

Li, C.-F., Chytry, M., Zeleny, D., \& Chen M.-Y. (2013). Classification of Taiwan forest vegetation. Applied Vegetation Science, $\mathbf{1 6}$ (4), 698- 719.

Li, P., \& Adams, W. T. (1993). Genetic control of bud phenology in pole-sized trees and seedlings of Douglas-fir. Canadian Journal of Forest Research , 23, 1043- 1051.

Loehle, C., \& Namkoong, G. (1987). Constraints on tree breeding: Growth tradeoffs, growth strategies, and defensive investments Forest Science, 33, 1089- 1097.

Matziris, D. I. (1994). Genetic variation on the phenology of flowering in black pine. Silvae Genetica, 43 , 321- 328 .

Maupetit, A., R. Larbat, R. Pernaci, M., Andrieux, A., Guinet, C., Boutigny, A.-L., Fabre, B., Frey, P., \& Halkett, F. (2018). Defense compounds rather than nutrient availability shape aggressiveness trait variation along a leaf maturity gradient in a biotrophic plant pathogen.Frontiers in Plant Scienc e, 9 (28 September 2018), https://doi.org/10.3389/fpls.2018.01396. Accessed December 23, 2020.

McArt, S. H., Koch, H., Irwin, R. E., \& Adler, L. S. (2014). Arranging the bouquet of disease: Floral traits and the transmission of plant and animal pathogens. Ecology Letters , 17 , 624- 634. https://doi.org/10.1111/ele.12257

McDougal, R. L., \&. Ganley, R.J. (2021). Foliar Phytophthora in New Zealand plantation forests: historical presence of Phytophthora kernoviae and association with a previously undiagnosed disorder of Pinus radiata . Australasian Plant Pathology, https://doi.org/10.1007/s13313-021-00825-w

Menzies, M. I., \& Holden, D. G. (1981). Seasonal frost-tolerance of Pinus radiata ,Pinus muricata, and Pseudotsuga menziesii. New Zealand Journal of Forestry Science, 11, 82- 99. 
Molles, M. C. (2002). Ecology: concepts and applications. Boston, MA, USA, Mc Graw-Hill. xviii + 586 p. Mulvey, R. L., Shaw, A. C., Filip, G. M., \& Chastagner, G. A. (2013). Swiss needle cast. USDA Forest Service Forest Insect and Disease Leaflet 181, 12p.

Mutz, J., R. McClory, R., van Dijk, L. J. A., Ehrlen, J., \& Tack. A. J. M. (2021). Pathogen infection influences the relationship between spring and autumn phenology at the seedling and leaf level. Oecologia ,197 , 447- 457. https://doi.org/10.1007/s00442-021-05044-0

Norskov-Lauritsen, G. (1963). Notes on the growth habits of the main pine species of the Eastern Transvaal Region. Forestry in South Africa, 3, 67- 83.

Old, K. M. (1981). Western gall rust, a serious disease of Pinus radiata in California. Australian Forestry , 44, 178- 184 .

Old, K. M., Libby, W. J., Russell, J. H., \& Eldridge, K. G. (1986). Genetic variability in susceptibility of Pinus radiata to western gall rust. Silvae Genetica, 35 :145- 149.

Osada, N. (2020). Intraspecific variation in spring leaf phenology and duration of leaf expansion in relation to leaf habit and leaf size of temperate tree species. Plant Ecology, 221 , 939- 950.

Panchen, Z. A., Primack, R. B., Nordt, B., Ellwood, E. R., Stevens, A.-D., Renner, S. S., Willis, G. C., Fahey, R., Whittemore, A., Du, Y., \& Davis, C. J. (2014). Leaf-out times of temperate woody plants are related to phylogeny, deciduousness, growth habit and wood anatomy.New Phytologist , 203 , 1200- 1219.

Pederick, L. A. (1979). Natural variation in shining gum (Eucalyptus nitens ). Australian Forest Research ,9, 41- 63 .

Poethig, R. S. (1990). Phase change and the regulation of morphogenesis in plants. Science 250, 923- 930.

Persoons, A., Morin, E., Delaruelle, C., Payen, T., Halkett, F., Frey, P., De Mita, S., \& Duplssis, S. (2014). Patterns of genomic variation in the poplar rust fungus Melampsora larici-populina identify pathogenesisrelated factors. Frontiers in Plant Science, 15 September $2014<$ https://doi.org/10.3389/fpls.2014.00450>

Powers, H. R., Schmidt, R. A., \& Snow, G. A. (1981). Current status and management of fusiform rust in southern pines. Annual Review of Phytopathology , 19, 353- 371.

Ramsfield, T. D., Kriticos, D. J., D., R. Vogler, D. R., \& Geils, B. W. (2007). Western gall rust - A threat to Pinus radiata in New Zealand. New Zealand Journal of Forestry Science, 37 , 143- 152

Rathcke B.J. \& Lacey, E. (1985). Phenological patterns of terrestrial plants. Annual Review of Ecology and Systematics, 16 , 179- 214.

Reich, P. B., Walters, M. B., \& Ellsworth, D. S. (1992). Leaf life-span in relation to leaf, plant and stand characteristics among diverse ecosystems. Ecological Monographs , 63 , 365- 392.

Singer, M.C., \& Parmesan, C. (2010). Phenological asynchrony between herbivorous insects and their hosts: signal of climatic change or pre-existing adaptive strategy? Philosophical Transactions of the Royal Society $B, 365,3161-3176$.

Skroppa, T., \& Steffenrem, A. (2019). Genetic variation in phenology and growth among and within Norway spruce populations from two altitudinal transects in Mid-Norway. Silva Fennica ,63 (1), article id 10076.

Smith, L., Primack, R. B., Zipf, L., Pardo, S., Gallinat, A. S., \& Panchen, Z. A. (2019). Leaf longevity in temperate evergreen species is related to phylogeny and leaf size. Oecologia , 191 , 483- 491.

Spiers, A. G. (1998). Melampsora and Marssonina pathogens of poplars and willows in New Zealand. European Journal of Forest Pathology, $28,233-240$.

Strauss, S. Y., Rudgers, J. A., Lau, J. A., \& Irwin, R. F. (2002). Direct and ecological costs of resistance to herbivory. TRENDS in Ecology and Evolution, 17 (6), 278- 285. 
Suc, J.-P. (1984). Origin and evolution of Mediterranean vegetation and climate in Europe. Nature, 307, 429- 432.

Van Krayenoord, C. W. S., Laundon, G. F., \& Spiers, A. G. (1974). Poplar rusts invade New Zealand. Plant Disease Reporter ,58 , 423- 427.

van Schaik C.P., Terborgh, J. W., \& Wright, S. J. (1993). The phenology of tropical forests: adaptive significance and consequences for primary consumers. Annual Review of Ecology and Systematics , 24, 353377 .

Van Valen, L. (1973). A new evolutionary law. Evolutionary Theory, 1, 1- 30.

Villar, R., Robleto, J. R., Jong, Y. D., \& Poorter H. (2006). Differences in construction costs and chemical composition between deciduous and evergreen woody species are small as compared to differences among families. Plant, Cell \& Environment .29, 1629- 1643.

Walker, J., Hartigan, D., \& Bertus, A. L. (1974). Poplar rusts in Australia with comments on potential conifer rusts. European Journal of Forest Pathology , 4, 100- 118.

Wareing, P. F. (1958). The physiology of cambial activity. Journal of the Institute of Wood Science, 1 , 3442.

Waterton, J., \& Cleland, E. E. (2016). Trade-off between early emergence and herbivore susceptibility mediates exotic success in an experimental California plant community. Ecology and Evolution ,6 , 89428953.

Wilkinson, A. G., \& Spiers, A. G. (1976). Introduction of the poplar rusts Melampsora larici-populina and M. medusae to New Zealand and their subsequent distribution. New Zealand Journal of Science, 19, 195198.

Zotz, G., Wilhelm, K., \& Becker. A. (2011). Heteroblasty-a review.Botanical Review , 77 , 109- 151.

Tables, Figures and Data Accessibility Statement :

None applicable

\section{Competing Interests Statement}

None

Author contributions

RDB drafted the manuscript and made final revisions, and MJB contributed revision and expansion. Both are agreed on final content.

\section{Acknowledgments}

We thank Gancho Slavov for encouragement to produce this article, Alvin Yanchuk and Dave Kelly for comments on early drafts and suggestions, Richard Primack for providing some references, and Stuart Fraser, Jennifer Lau and anonymous reviewers for helpful comments and suggestions. RDB was in receipt of office facilities from Scion, and MJB.'s contribution was covered by the New Zealand Ministry for Business Innovation and Employment through the Science Strategic Investment Fund (administered by Scion, the New Zealand Forest Research Institute Ltd). 